\title{
Abordagem
}

Florestan Fernandes

\section{A percepsão popular da Assembléia Nacional Constituinte}

A sociologia dos mandarins fugiu dos temas concretos. Hoje se fala no imaginário e nas suas relações com o simbólico. Porém, não se faz uma análise objetiva das representações. Voltamos a Hegel de uma forma perversa, como se a sociedade não tivesse história e essa fosse uma expressão metafísica das "construções mentais" do sociólogo, não "a atividade do homem que persegue seus objetivos" (ENGELS, 1844). O que é a Assembléia Nacional Constituinte? $\mathrm{O}$ imaginário das elites das classes dominantes ou de seus escribas? Ou uma formação política parida da crise cataclísmica de uma sociedade civil que se tornou inviável para quase cem milhões de exclurdos e de oprimidos, ou de trabalhadores que a ela são incorporados morfologicamente, mas privados, pelos dinamismos de repressão e de opressão, de peso e voz em sua ordenação e funcionamento? Os partidos da ordem e os políticos profissionais trabalharam a consciência social desses exclurdos, desses oprimidos, desses trabalhadores que entram subterraneamente na história, pelas portas dos fundos. A campanha eleitoral teve esse alvo: difundir a ideologia dos estratos dominantes das classes burguesas. Assim, ampliam e aprofundam sua coisificação, iniciada nas fábricas, prolongada nas escolas e nas igrejas, completada nos sindicatos e nos partidos comprometidos com o melhorismo, o obreirismo pacifico, a alienação refinada e aguçada graças ao consumismo de massa e à indústria da comunicação cultural.

Todavia, o que fez esse desgraçado da terra com as ideias, os ideais, os valores - em suma, os símbolos pelos quais bucavam fazer sua cabeça, decapitá-lo como agente histórico e político? Ele os introjetou nos proprios termos de sua miséria e da negação do que lhe era negado. A ANC converteu-se em um foco de luz, de esperança - uma promessa que não cabia no imaginário das elites das classes dominantes e no realismo de seus políticos profissionais. A iniciativa popular foi organizada $e$ desencadeada de cima para baixo, por entidades bem conhecidas, tendo à frente a CNBB, a $\mathrm{OAB}$, as comunidades de base e várias outras organizações, entre as quais se contavam sindicatos, federações sindicais, partidos de esquerda, faç̧ões radicais dos partidos da ordem (no caso especialmente $O$ PMDB e 0 PFL). Contudo, é preciso distinguir a iniciativa popular do significado da presença e das compulsões mentais e sociais dos de baixo. Esta última polaridade, mais ou menos escamoteada, surgiu espontaneamente. Ela estava no sangue do pobre, dos mais humildes, e na consciência contestadora dos trabalhadores mais organizados e mais decididos em tomar seus destinos nas próprias mãos. Na cabeça dessa gente, por motivações opostas, o imaginário das elites era conversa fiada. Essa gente forjou um antiimaginário contra-litista, que atravessa a realidade brasileira como um punhal afiado, fundado em suas representações, que não refletem uma imagem invertida de suas condições de vida. Queriam vários tipos de reforma social simultaneamente e, por quererem esses tipos de reforma social, tentaram decifrar a seu modo a ANC e suas tarefas imediatas. É uma ilusão de mandarins supor que a falta de educação

* Texto reproduzido, com permissão do autor, da Folha de S. Paulo, 11 de abril de 1988. Seçāo Opiniāo - Tendências/Debates, p. A-3. 
ou a ignorância inibiram tal gente e a jogariam no colo dos ricos, no modelo de Constituição que os mandachuvas desejavam e iriam elaborar.

Sem proceder a sondagens emprícas sistemáticas, mas ouvindo atenta e intensivamente aqui e ali, infelizmente apenas circulando entre os que sabem que a Constituição en tre tém relações com suas vidas (deve ser incontável o número dos que não sabem que existe uma ANC), cheguei a algumas conclusões consistentes. Há uma categoria maior de pessoas pobres e de trabalhadores que se defende passivamente. Eles não são propriamente indiferentes. Possuem informações, saem de si mesmos, mas protegem-se de maneira a elidir-se ou esquivar-se dos golpes mais demolidores. Depositavam esperanças na ANC, que despontava como uma solução dos nossos problemas. Os falatórios, somados às repercurssões sociais da mídia, levaram-nos à desilusāo. Algo tão distante e complexo, como a rede do poder, carrega consigo a carga dúbia de que não poderia ser de outro modo. Por que, de uma hora para outra, só porque queremos, a Constituição iria responder às agruras dos pobres? De uma forma mais confusa aqui, mais clara acolá, a Constituição ficou em seu lugar: aqueles que a fazem, a entendem, a manejam. A frustação é forte e o deputado ou senador recebe o seu quinhão. Ele prometeu e não cumpriu, como sempre; seguindo a nova onda, dizem que vive como um marajá. 0 que era uma esperança esfumou-se, metamorfoseando-se em raiva larvar recalcada dos que nunca têm vez e por isso estão condenados a não encon trar promessas numa rotina de pobreza secular.

Os partidos da ordem e os políticos profissionais trabalharam a consciência social desses exclurdos, desses oprimidos, desses trabalhadores que entram subterraneamente na história, pelas portas dos fundos.
Ao lado desses, e com eles interagindo, está um conglomerado de informados e que chegaram a ser acordados para uma esperança mais alvoroçada e confiante, pelas comunidades de base, pelas associações de bairros, pela participação em comícios, pela mídia e uma infindável variedade de outro meios. A ANC não é identificada cóm o poder e com a dominação de classe. Desvenda-se como qual poderiam esperar um produto algo comparável à Escola ou à Igreja, da construtivo, capaz de melhorar as suas vidas. De novo, a instituição é encarada como um meio, só que com maior confiança e como um meio para atingir os fins comuns, de todos, pobres e ricos. A Constituição estaria para os pobres como um instrumento de alteração de realidades nuas e cruas. Essa percepção poderá parecer infantil, porém não é; foi elaborada como resposta à constância das humilhações e sofrimentos, sob influência de pessoas instruídas e devotadas à conscientização dos humildes. Nessa esfera, prepondera uma insuperável ambigüidade $\mathrm{e} a$ tendência moderada de concordar com os que enfatizam que a Constituição possui coisas boas e que poderá melhorar nossas vidas, se as soubermos usar. Não obstante, a peneira não tapou a luz do sol. Há inquie tação e, principalmente, uma dolorosa constatação. As grandes reformas sociais já são transferidas para diante, para a açāo do próprio povo organizado. Não se diz isso, mas as conversas deixam implícito que os constituintes não trataram os interesses populares com ardor, e que muitos preferiram omitir-se ou atraiçoar os que votaram neles. Em consequiência, a ausência de raiva é pior do que operasse a sua objetivação. A descrença fria e rústica envolve um repúdio reprimido. Pode converter-se em seu oposto em um fiat, mesmo sob uma chama pequena, desde que se conclame a todos a tomar a justiça em suas mãos.

Por fim, aparece a vanguarda proletária, que descobri ser tão vigorosa entre os operários, quanto entre os trabalhadores da terra (acompanhando-os a um ex-ministro da Reforma Agrária, verifiquei que são destemidos $\mathrm{e}, \mathrm{em}$ confronto com o antigo mandonismo, atrevidos, falando de igual para igual com o ministro e numa linguagem direta, exigente). Os operários são mais numerosos e melhor organizados; dão o seu combate em várias frentes e dispõem de meios institucionais de luta de classes. No entanto, os trabalhadores da terra ganharam muito terreno, apesar da ditadura militar e da nova República. Para essa vanguarda social, a Constituição possuía um significado concreto: erradicar a pobreza, o desemprego, as doenças, a falta de escolas, o latifúndio 
etc. $\AA$ impulsão de quierer ser gente se associava uma consciência social atenta aos interesses dos trabalhadores e aos privilegios dos patrões. Dispersos por sindicatos, federaçōes e partidos, distribuem-se por diversas correntes, grupos e subgrupos. A eles se agrega uma enorme multiplicidade de companheiros de viagem, pertencentes à pequena burguesia ou aos setores em descensão social das classes médias. Não se poderia detectar, nesse caleidoscópio social, percepçőes homogêneas. Socializados por partidos políticos e correntes ideológicas díspares, alimentam ilusóes e desilusōes contrastantes. Os mais extremados colocam os pingos nos is simplesmente: a Constituição abre novos horizontes e traz algumas conquistas.

Mas tudo isso não passa de migalhas. 0 povo terá de conquistar poder para chegar a uma Constituição verdadeiramente democrática. Os menos maduros na politização manifestam-se estranhamente, como os mais revoltados. $O$ retrato que esboçam dos constituintes, no conjunto, é de perfil baixo. $O$ ódio ferve, como o azeite em um caldeirão. $O$ tratamento dispensado a deputados e senadores do PMDB em diversos comíciós ou ao presidente em exercício contém um paradigma. Nessa área, o vulcão vomita lavas e o clima latente é de guerra civil.

Mesmo a esquerda é atacada, por ainda não ter-se retirado da ANC, e a assinatura da próxima Carta Magna propõe-se como um dilema, a ser enfrentado pelos partidos.
Esse contexto, exposto sumariamente, sugere que há algo mais profundo na reação de certas entidades operárias ao decidirem estampar e difundir os cartazes do "Procura-se. .. ". O expediente foi mal avaliado por muitos constituin tes, particularmente os conservadores e os liberais ou radicais que se sentiram (e por vezes foram) injustiçados. Ora, a avaliação muda de figura quando se leva em conta essas correntes psicológicas e políticas mais profundas do comportamento coletivo, nas quais a aparência não se confunde com a essência. 0 protesto sobe à tona ameaçador, carregando uma mensagem que diz taxativamente "nao!" e "basta!", em vários tons. Estamos sendo julgados, não estamos julgando. Uma ANC que se curvou à prepotência do sistema de poder existente $e$, por sua maioria conservadora, representa não o poder originário e soberano do povo, mas os particularismos das classes privilegiadas e as ambições das nações capitalistas hegemônicas, tem muito o que aprender e o que temer diante dos ressentimentos e frustrações da massa subalterna dos. cidadãos. Ambos, ressentimentos e frustrações, acarretam violência e agressão. Seria melhor receber o recado e mudar o estilo de produção constitucional. Há grosserias que são detestáveis, mas possuem raízes historicas pelas quais passado e presente se ligam à construção do futuro. E a nação, nesses estratos, só quer socialmente uma coisa: uma revolução democrática irreversf́vel. 